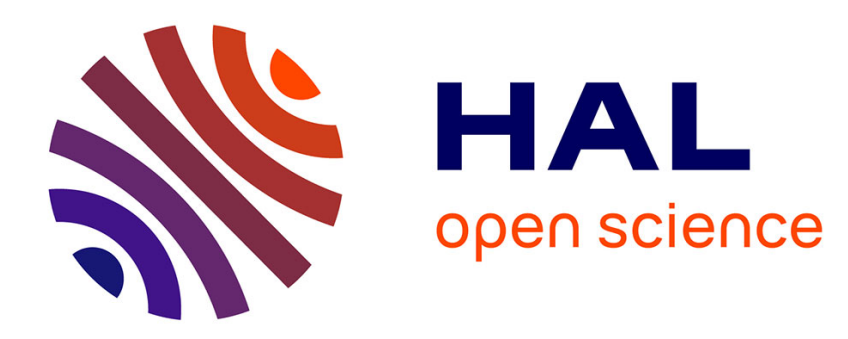

\title{
Ferrite Industry in India. Present Scenario and Future Outlook
}

S. Sarnot, A. Mathur, R. Govila

\section{To cite this version:}

S. Sarnot, A. Mathur, R. Govila. Ferrite Industry in India. Present Scenario and Future Outlook. Journal de Physique IV Proceedings, 1997, 07 (C1), pp.C1-31-C1-34. 10.1051/jp4:1997103 . jpa00254713

\section{HAL Id: jpa-00254713 https://hal.science/jpa-00254713}

Submitted on 1 Jan 1997

HAL is a multi-disciplinary open access archive for the deposit and dissemination of scientific research documents, whether they are published or not. The documents may come from teaching and research institutions in France or abroad, or from public or private research centers.
L'archive ouverte pluridisciplinaire HAL, est destinée au dépôt et à la diffusion de documents scientifiques de niveau recherche, publiés ou non, émanant des établissements d'enseignement et de recherche français ou étrangers, des laboratoires publics ou privés. 


\title{
Ferrite Industry in India. Present Scenario and Future Outlook
}

\author{
S.L. Sarnot, A. Mathur and R.K. Govila* \\ Department of Electronics, Government of India, New Delhi, India \\ * Electronics Materials Industry Association (ELMINA), New Delhi, India
}

\begin{abstract}
:-
Present Indian ferrite industry has come long way. Commercial production of ferrites started in 1960 's. The production of ferrites in 1990 was about 7000 MT which has grown to ahout 15000 MT by 1995 indigenously. Indian ferrite industry is now posed for big jump and now getting rendy to compele in the world market. "The major companies are now proposing for big expansions in their production capacitics with a desire to become global player. These plans hive got further boost due to new cconomic relorms initiated by the Govt. of India and helping the industry to incrense their share in world lerrite marke. The new liberalised policy of Inclian Govt. lave also attracted many loreign companies to sel up their production bises in India. The present paper deals in detail the scenario of the fndian industry, availability of main inpul raw materinls, new Gove. policies, opportunities for new ventures etc.
\end{abstract}

\section{Introduction:}

Ferrites have been established as one of the importan magnetic material and conlinue to fulfill the needs of the rapidly growing electronic, automobile, household and other sectors of industry. Broadly, ferrites can be divided into two categorjes namely, hard and soft ferrites. Indian ferrite industry started about 30 years ago with production of radio ferrites in soft ferrite category by $\mathrm{M} / \mathrm{s}$ Morris Electronics, Pune. Later on, another company was established under public sector utilising locally developed technology. From the scene of early seventies where only two companies were involved in production of ferrites, India today has about 20 major companies producing soft and hard ferrites. In the following paragraphs a review of the Indian ferrite industry is presented and inherent Indian advantages for the growth of this industry in India is discussed.

\section{Production Scenario:}

From the time of ICF-5, which was held in India in 1988, ferrite production has increased manyfold. While the production of soft ferrite has increased from $1161 \mathrm{MT}$ in 1988 to $3282 \mathrm{MT}$ in 1995, that of hard ferrite this has increased from $3815 \mathrm{MT}$ to $9156 \mathrm{MT}$ respectively. The growlh pattern of Ferrite production for soft and hard categories for the last 10 years is depicted in the following figures.

\section{PRODUCTION GROWTH}

\section{SOFT FERRITE}

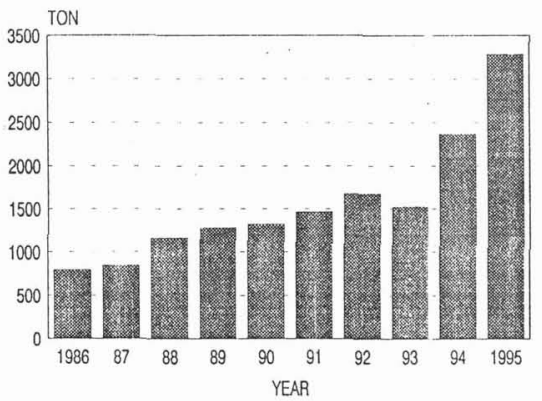

HARD FERRITE

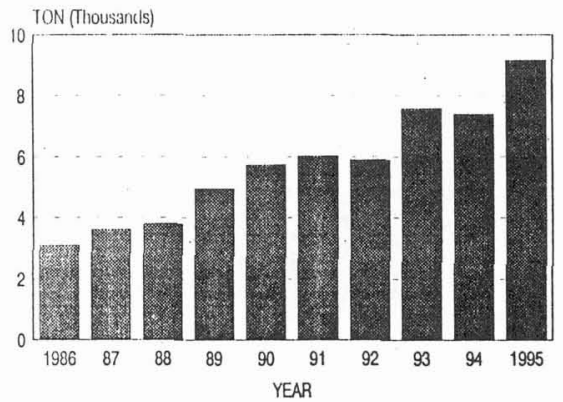


At present, Indian production is meeting almost full demand of hard ferrites except some specific requirements of micromotors and high energy magnets/segments. In the soft ferrite sector, deflection yoke for the CTV and some specific requirements of telecommunications sector are met through imports.

\section{Export Scenario:}

During 1995, India has exported 540 MT of soft ferrites and $1700 \mathrm{MT}$ of hard ferrites. The export growth of soft \& hard ferrites is shown below.

\section{EXPORT GROWTH}

\section{SOFT FERRITE}

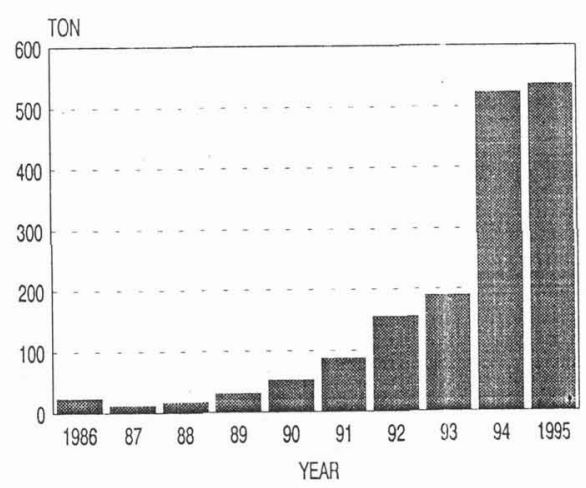

HARD FERRITE

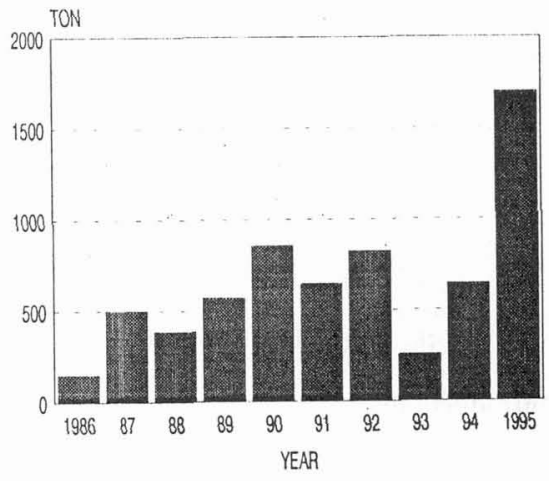

Some of manufacturers have been taken lead in exporting ferrite components as well as pre-calcined powder. India today has capacity to manufacture $3,700 \mathrm{MT}$ per yeal of solt territe and about $12,000 \mathrm{MT}$ of hard ferrite material. Many of the international players like. Siemens, (iermany; I.CC, France; Krupp, Germany; Nippon Ferrites, Japan; Hitachi Metals, Jipan; Samhwa, Korea; Saikai-Japan; have collahoration with Indian companies.

\section{Demand forecast :}

Keeping in view of the high growth rate (20\% to $40 \%$ p.a.) in the areas of C.TV, computer and peripherals, telecommunications and lighting sector and nominal growth $(5 \% 1018 \%)$ in the area of audio, B\&W TV, automobile and loudspeaker sectors, following demand his been estimated for hild and soft ferrite components:

\begin{tabular}{|lrrrr|}
\hline & 1996 & 1998 & 2000 & 2005 \\
\hline Hard & 8000 & 10,000 & 12,000 & $30,000 \mathrm{MT}$ \\
Soft & 3400 & 4,800 & 7,000 & $15,000 \mathrm{MT}$ \\
\hline
\end{tabular}




\section{Advantages of producing ferrites in India :}

\section{(a) Raw Material Availability :}

The ferrite industry can be classified as high capital and conergy intensive industry with large variety of products in both hard and soft categories requiring high degree of technology and stringent physical tolerance. The industry requires raw material like Ferric oxide, Oxides of Manganese Zinc oxide, Barium Carbonate and Strontium Carbonate etc., of various specifications. Out of this, Ferric oxide is the major constituent which is consumed almost $80 \%$ by weight in all the products. India is bestowed with large resources of this basic and main input material. Bailadilla range in central part of the country, is one of the largest mines of iron ore in India. In this mine huge quantity (approx. 20 million tonnes) of naturally occurring fine particle, high grade iron oxide called 'Bluedust' is available. By subjecting it to physical beneficiation, high grade ferric oxide material (silica content upto $0.2 \%$ ) is obtained which is suitable for hard ferrite applications as well as for some categories of soft ferrites. In addition, India has started producing high purity $\mathrm{Fe}_{2} \mathrm{O}_{7}$ through chemical route as well. The details of the present and future production capacities of Iron Oxide are given in the following table:

\begin{tabular}{|c|c|c|c|}
\hline \multirow[b]{2}{*}{ S.No. } & \multirow[b]{2}{*}{ Type of Iron Oxide } & \multicolumn{2}{|c|}{ Capacity(MT) } \\
\hline & & Present & Future additions \\
\hline 1. & Upgraded Magnetite & 1,000 & 3,000 \\
\hline 2. & Upgraded Hematite & 10,000 & $.8000-10,000$ \\
\hline 3. & $\begin{array}{l}\text { Spray Roasted Ferric } \\
\text { Oxide } \mathrm{SiO} 2>200 \mathrm{ppm}\end{array}$ & 500 & $800\left(10^{* x}+13,0000^{* x}\right.$ \\
\hline 4. & $\begin{array}{l}\text { Spray Roasted Ferric } \\
\text { Oxide } \mathrm{SiO} 2<200 \mathrm{ppm}\end{array}$ & 10,000 & $\begin{array}{l}600100^{*}+10,000^{*+*} \\
12000^{* *} \mathrm{MT}\end{array}$ \\
\hline
\end{tabular}

Till recently India was importing all its requirement of oxides of manganese but now one company in the private sector has started production of good quality $\mathrm{Mn}_{3} \mathrm{O}_{4}$. Zinc Oxide and Barium Carbonate are available easily in the country. However, to manufacture Strontium Ferrites, Strontium Carbonate is being imported.

\section{b) Research \& Development Base:}

Contemporary technologies related to ferrites production are alrcady alsorbed in the country. There is wide spread infrastructure of various acadernic institutions and rese:urch labs. Core lacilities for the chanacterisation of the materials and for making various me: surements retaled to magnetic properties are available in the following institutions:-

Indian Institute of Technology, Bombily,

National Chemical Lationatory, Pouni,

Indian Institute of Seience, Bangalore.

National Metallurgical Laboratory, Jamshedpur.

National Mineral Development Corp., Hyderabad.

Indian Institute of Technology, Madras.

Solid State Physics Laboratory, Delhi. 
Department of Electronics, (DOE) Govt. of India has played a catalytic role in creating the environment for setting up of industry and R\&D base in India. Following is a list of some of the R\&D projects successfully completed recently under the sponsorship of DOE:- -

\begin{tabular}{|l|l|l|}
\hline Agency & Funded by & Process developed \\
\hline $\begin{array}{l}\text { Solid State Physics } \\
\text { Laboratory, Delhi }\end{array}$ & DOE, DRDO & $\begin{array}{l}\text { Microwave ferrites } \\
\text { (Lithium \& Garnet) }\end{array}$ \\
NMDC, Hyderabad & DOE, NMDC & $\begin{array}{l}\text { Pilot Plant for beneli- } \\
\text { ciation of Bluedust }\end{array}$ \\
CEL, Sahibabad & DOE, CEL & $\begin{array}{l}\text { High permeabitity ferrites } \\
\text { u }>7000 .\end{array}$ \\
NMDC, Hyderabad & DOE, NMDC & $\begin{array}{l}\text { Research is being done for } \\
\text { the development of ferrite } \\
\text { powder using indigenous } \\
\text { sources of ferric oxide. }\end{array}$ \\
\hline
\end{tabular}

\section{c) Liberalised Government Policies :}

India has today new industrial policy which is transparent and quick and has eliminated licensing from this sector. The salient features of industrial policy are given below:-

i) There is no reservation for public sector enterprises and investment by private sector is welcome.

ii) The industry can be set up any where in the country subject to clearance from the point of view of environmental pollution.

iii) Foreign Direct Investment (FDI) gets automatic permission for foreign equity upto $51 \%$, provided foreign equity covers entire cost of imported capital gorods.

iv) Non-resident Indians get automatic approval upto $100 \%$ eguity.

v) Foreign investment of upto $100 \%$ is permitted in units set-up solely for exports.

vi) Various incentives and concessions are avaibable for export-oriented units, like duty free import of raw-materials, components and other inputs as well as capital goods.

\section{Future Prospects:}

As depicted above, the raw materials required for the production of ferrite in India is now easily available. A good scientific base and infrastructure is already established and trained manpower, which is more economical than many European countries, is available. The incentives provided by the Government for export of ferrites components alongwith the above mentioned advantages put India into a situation where it can be a major producer and exporter of territe products. Indian companies as well as a tew multinational companies have recognised these advantages and planning to increase/setup new capacities for the production of ferrites. It is estimated that by the year 2000AD India will have capability to produce $10,000 \mathrm{MT}$ of soft-ferrite and $18,000 \mathrm{MT}$ of hard ferrite and may emerge as an important player in the ferrite sector. A fter meeting the internal clemand, it is estimated that India shall be able to export $6000 \mathrm{MT}$ of Hard Ferrites and about $3000 \mathrm{MT}$ of Soft Ferrites by the turn of this century. 